\title{
Malnutrition inflammation index in chronic haemodialysis patients with or without hepatitis $C$ virus infection
}

\author{
Fardous Abdel Fattah Ramadan ${ }^{1}$, Nancy Abdel Fattah Ahmed ${ }^{1 *}$, Salah Elshahat Aref ${ }^{1}$ and \\ Mona Abdel Ghani El Husseini²
}

\begin{abstract}
Background: Hepatitis C virus infection is one of the main causes of chronic liver disease worldwide. Both chronic hepatitis $\mathrm{C}$ and chronic kidney disease are common and serious diseases; this work aimed to determine the clinical impact of HCV infection on malnutrition inflammation index score in chronic kidney disease patients.

This study was conducted on 96 patients on haemodialysis. They were divided into two groups. The first group was composed of 46 patients who were on maintenance haemodialysis and had chronic hepatitis C. The second group was composed of 50 patients on haemodialysis who were negative for hepatitis $C$.
\end{abstract}

Results: HCV-infected patients were associated with higher malnutrition inflammation score values (10\% had MIS 16-20) compared to non-infected patients (2\% only had MIS 16-20).

Conclusion: The prevalence of malnutrition was higher in the HCV-positive than the HCV-negative group.

Keywords: HCV, CKD, MIS

\section{Background}

HCV infection is one of the main causes of chronic liver disease worldwide [1]. The number of infected persons may be about 160 million, but most are unaware of their infection [2]. The long-term impact of HCV infection is highly variable from minimal changes to extensive fibrosis and cirrhosis with or without hepatocellular carcinoma [1]. Both HCV and chronic renal disease are common and potentially serious diseases [3]. Patients undergoing maintenance haemodialysis have a significantly higher prevalence of $\mathrm{HCV}$ infection and malnutrition inflammation complex syndrome (MICS) [4]. Malnutrition causes cardiovascular mortality in dialysis patients [5] and decreases the quality of life of haemodialysis patients [6].

\footnotetext{
* Correspondence: ziad.emad90@yahoo.com

${ }^{1}$ Faculty of Medicine, Mansoura University, Mansoura, Egypt

Full list of author information is available at the end of the article
}

This work aimed to determine the clinical impact of $\mathrm{HCV}$ infection on malnutrition inflammation index score in chronic kidney disease patients.

\section{Methods \\ Design of the study}

Our patients in this study were selected from those who attended Sherbeen Central Hospital (Dakahlia), Haemodialysis Unit.

\section{Sample size and selection of the patients \\ This study was conducted on 96 patients (61 males and 35 females) on haemodialysis from April 2016 to December 2016, and they were divided into two groups: the first is 46 haemodialysis patients with positive $\mathrm{HCV}$ infection; the second is 50 haemodialysis patients with}

(c) The Author(s). 2020 Open Access This article is licensed under a Creative Commons Attribution 4.0 International License, which permits use, sharing, adaptation, distribution and reproduction in any medium or format, as long as you give appropriate credit to the original author(s) and the source, provide a link to the Creative Commons licence, and indicate if changes were made. The images or other third party material in this article are included in the article's Creative Commons licence, unless indicated otherwise in a credit line to the material. If material is not included in the article's Creative Commons licence and your intended use is not permitted by statutory regulation or exceeds the permitted use, you will need to obtain permission directly from the copyright holder. To view a copy of this licence, visit http://creativecommons.org/licenses/by/4.0/. 
negative $\mathrm{HCV}$ infection. Patient ages range between 20 and 60 years.

\section{Inclusion criteria}

The inclusion criteria are as follows: chronic kidney disease patients on haemodialysis and patients aged from 20 to 60 years.

\section{Exclusion criteria}

The exclusion criteria are as follows: patients who had clinical or laboratory evidence of active infectious disease 1 month before the study onset and patients with history of tumours.
Methods of the study

They were evaluated by Malnutrition-Inflammation Score, and clinical examination with special stress on some items (Fig. 1).

\section{Laboratory investigations}

These are as follows: serum calcium, potassium, and sodium; complete blood count (CBC); blood urea; serum creatinine; C-reactive protein (CRP); ELISA for HCV antibody; PCR for hepatitis C-positive ELISA patients; total iron-binding capacity (TIBC); and serum transferrin.

\begin{tabular}{|c|c|c|c|}
\hline \multicolumn{4}{|c|}{ MALNUTRITION INFLAMMATION SCORE (M.I.S.) } \\
\hline \multicolumn{4}{|c|}{ (A) Patients' related medical history: } \\
\hline \multicolumn{4}{|c|}{ 1- Change in end dialysis dry weight (overall change in past 3-6 months): } \\
\hline 0 & 1 & 2 & 3 \\
\hline $\begin{array}{l}\text { No decrease in dry weight } \\
\text { or weight loss }<0.5 \mathrm{~kg}\end{array}$ & $\begin{array}{l}\text { Minor weight loss } \\
(\geq 0.5 \mathrm{~kg} \text { but }<1 \mathrm{~kg})\end{array}$ & $\begin{array}{l}\text { Weight loss more than } \\
\text { one kg but }<5 \%\end{array}$ & Weight loss $>5 \%$ \\
\hline \multicolumn{4}{|l|}{ 2- Dietary intake: } \\
\hline 0 & 1 & 2 & 3 \\
\hline $\begin{array}{c}\text { Good appetite and no } \\
\text { deterioration of the dietary } \\
\text { intake pattern }\end{array}$ & $\begin{array}{l}\text { Somewhat sub-optimal } \\
\text { solid diet intake }\end{array}$ & $\begin{array}{l}\text { Moderate overall decrease } \\
\text { to full liquid diet }\end{array}$ & $\begin{array}{l}\text { Hypo-caloric liquid to } \\
\text { starvation }\end{array}$ \\
\hline \multicolumn{4}{|c|}{ 3- Gastrointestinal (GI) symptoms: } \\
\hline 0 & 1 & 2 & 3 \\
\hline $\begin{array}{l}\text { No symptoms with good } \\
\text { appetite }\end{array}$ & $\begin{array}{l}\text { Mild symptoms, poor } \\
\text { appetite or nauseated } \\
\text { occasionally }\end{array}$ & $\begin{array}{l}\text { Occasional vomiting or } \\
\text { moderate GI symptoms }\end{array}$ & $\begin{array}{c}\text { Frequent diarrhea or } \\
\text { vomiting or severe } \\
\text { anorexia }\end{array}$ \\
\hline \multicolumn{4}{|c|}{ 4- Functional capacity (nutritionally related functional impairment): } \\
\hline 0 & 1 & 2 & 3 \\
\hline $\begin{array}{c}\text { Normal to improved } \\
\text { functional capacity, feeling } \\
\text { fine }\end{array}$ & $\begin{array}{l}\text { Occasional difficulty with } \\
\text { baseline ambulation, or } \\
\text { feeling tired frequently }\end{array}$ & $\begin{array}{l}\text { Difficulty with otherwise } \\
\text { independent activities (e.g. } \\
\text { going to bathroom) }\end{array}$ & $\begin{array}{l}\text { Bed/chair-ridden, or little } \\
\text { to no physical activity }\end{array}$ \\
\hline \multicolumn{4}{|c|}{ 5- Co-morbidity including number of years on Dialysis: } \\
\hline 0 & 1 & 2 & 3 \\
\hline $\begin{array}{l}\text { On dialysis less than one } \\
\text { year and healthy otherwise }\end{array}$ & $\begin{array}{l}\text { Dialyzed for } 1-4 \text { years, or } \\
\text { mild co-morbidity } \\
\left(\text { excluding } M^{-} C^{\star}\right)\end{array}$ & $\begin{array}{l}\text { Dialyzed }>4 \text { years, or } \\
\text { moderate co-morbidity } \\
\text { (including one } \mathrm{MCC}^{\star} \text { ) }\end{array}$ & $\begin{array}{c}\text { Any severe, multiple co- } \\
\text { morbidity }(2 \text { or more } \\
\left.\text { MCC }{ }^{\star}\right)\end{array}$ \\
\hline \multirow{2}{*}{\multicolumn{4}{|c|}{$\begin{array}{l}\text { (B) Physical Exam (according to SGA criteria): } \\
\text { 6- Decreased fat stores or loss of subcutaneous fat }\end{array}$}} \\
\hline & & Ww eyes, triceps, biceps, ch & \\
\hline \multirow{2}{*}{$\begin{array}{c}0 \\
\text { Normal (no change) }\end{array}$} & 1 & 2 & 3 \\
\hline & mild & moderate & Severe \\
\hline \multicolumn{4}{|c|}{ 7- Signs of muscle wasting (temple, clavicle, scapula, ribs, quadriceps, knee, interosseous): } \\
\hline 0 & 1 & 2 & 3 \\
\hline Normal (no change) & mild & moderate & Severe \\
\hline \multicolumn{4}{|l|}{ (C) Body mass index: } \\
\hline \multicolumn{4}{|c|}{ 8- Body mass index: $\mathrm{BMI}=\mathrm{Wt}(\mathrm{kg}) / \mathrm{Ht}^{2}(\mathrm{~m})$} \\
\hline 0 & 1 & 2 & 3 \\
\hline $\mathrm{BMl}>20 \mathrm{~kg} / \mathrm{m}^{2}$ & BMI: $18-19.99 \mathrm{~kg} / \mathrm{m}^{2}$ & BMI: $16-17.99 \mathrm{~kg} / \mathrm{m}^{2}$ & $\mathrm{BMI}<16 \mathrm{~kg} / \mathrm{m}^{2}$ \\
\hline \multicolumn{4}{|c|}{ (D) Laboratory Parameters: } \\
\hline \multicolumn{4}{|l|}{ 9- Serum albumin: } \\
\hline 0 & 1 & 2 & 3 \\
\hline Albumin $\geq 4.0 \mathrm{~g} / \mathrm{dL}$ & Albumin: $3.5-3.9 \mathrm{~g} / \mathrm{dL}$ & Albumin: $3.0-3.4 \mathrm{~g} / \mathrm{dL}$ & Albumin: $<3.0 \mathrm{~g} / \mathrm{dL}$ \\
\hline \multicolumn{4}{|c|}{ 10- Serum TIBC (total Iron Binding Capacity): * } \\
\hline 0 & 1 & 2 & 3 \\
\hline $\mathrm{TIBC} \geq 250 \mathrm{mg} / \mathrm{dL}$ & TIBC: $200-249 \mathrm{mg} / \mathrm{dL}$ & TIBC: $150-199 \mathrm{mg} / \mathrm{dL}$ & TIBC: $<150 \mathrm{mg} / \mathrm{dL}$ \\
\hline
\end{tabular}

Fig. 1 MIS. *Major comorbid conditions included congestive heart failure class III or IV, full-blown AIDS, severe coronary artery disease, moderate to severe chronic obstructive pulmonary disease, major neurologic sequelae, and metastatic malignancies or recent chemotherapy Suggested equivalent increments for serum transferrin are > 200 (0), 170 to 200 (1), 140 to 170 (2), and <140 mg/dL [7] 
Table 1 Baseline data for included HCV-non-infected and HCVinfected haemodialysis patients

\begin{tabular}{llll}
\hline Parameter & $\begin{array}{l}\text { HCV-non- } \\
\text { infected }\end{array}$ & $\begin{array}{l}\text { HCV- } \\
\text { infected }\end{array}$ & P value \\
\hline No. (\%) & $50(52.1 \%)$ & $46(47.9 \%)$ & - \\
Gender (male/female) & $29 / 21$ & $32 / 14$ & 0.241 \\
Height (cm) (mean \pm SD) & $165.2 \pm 0.5$ & $164.2 \pm 0.8$ & 0.427 \\
Body weight (kg) (mean \pm SD) & $\mathbf{7 0 . 2} \pm \mathbf{2 . 2}$ & $\mathbf{6 6 . 1} \pm \mathbf{2 . 3}$ & $\mathbf{0 . 1 9 6}$ \\
\hline
\end{tabular}

No number of patients, $S D$ standard deviation, $B M I$ body mass index. $P$ value: $P>0.05$ is non-significant and $P<0.05$ is significant. The basic demographics of the two groups were similar, and there was no significant difference between the two groups of subjects; $P>0.05$ in height, body weight, and BMl

\section{Statistical analysis}

All statistical analyses were performed by using the Statistical Package for the Social Sciences (SPSS) software version 15.0 (SPSS Inc., Chicago, IL) and GraphPad Prism package v.5.0 (GraphPad Software, San Diego, CA). Continuous variables were expressed as mean \pm standard deviation (SD). ANOVA or Student's $t$ test for continuous variables and chi-square $\left(x^{2}\right)$ for categorical variables were used to determine differences between groups. A $P$ value of $<0.05$ was considered statistically significant. The correlation coefficients $(r)$ were assessed by Pearson's correlation coefficient or Spearman's correlation coefficient as appropriate.

\section{Results (Table 1)}

Independent sample $t$ test showed that there was no significant difference $(P>0.05)$ between the two groups of subjects in the count of red blood cells, white blood cells, and platelets. In addition, there was no significant difference $(P>0.05)$ in haemoglobin levels between the two groups (Tables 1 and 2).

Independent sample $t$ test revealed that there were no significant differences $(P>0.05)$ between the two groups as regards serum iron markers (TIBC and serum transferrin) and CRP levels, while there were highly significant

Table 2 Comparison of haematology parameters between HCVnon-infected and HCV-infected haemodialysis patients

\begin{tabular}{llll}
\hline Parameter $^{\mathrm{a}}$ & \multicolumn{2}{c}{ Mean $\pm \mathrm{SD}^{\mathrm{b}}$} & $P$ value $^{\mathrm{c}}$ \\
\cline { 2 - 3 } & HCV-non-infected & HCV-infected & \\
\hline Haemoglobin $(\mathrm{g} / \mathrm{dL})$ & $8.8 \pm 0.2$ & $8.4 \pm 0.2$ & 0.129 \\
RBCS $\left(\times 10^{12} / \mathrm{L}\right)$ & $3.2 \pm 0.1$ & $3.1 \pm 0.1$ & 0.576 \\
WBCS $\left(\times 10^{9} / \mathrm{L}\right)$ & $6.5 \pm 0.3$ & $7.0 \pm 0.4$ & 0.454 \\
Platelet count $\left(\times 10^{9} / \mathrm{L}\right)$ & $205.3 \pm 8.3$ & $196.7 \pm 7.7$ & 0.278 \\
\hline
\end{tabular}

Reference ranges: red blood cell count: male $4.32-5.72 \times 10^{12}$ cells/L, female 3.90 $5.03 \times 10^{12}$ cells/L; haemoglobin: male $13.5-17.5 \mathrm{~g} / \mathrm{dL}$, female $12.0-15.5 \mathrm{~g} / \mathrm{dL}$; white blood cell count-3.5-10.5 $\times 10^{9}$ cells/L; platelet count-150-450 × 109 /L37 ${ }^{\mathrm{b}} S D$ standard deviation

${ }^{c} P$ value: $P>0.05$ is non-significant and $P<0.05$ is significant
Table 3 Comparison of renal function parameter between HCVnon-infected and HCV-infected haemodialysis patients

\begin{tabular}{llll}
\hline Parameter $^{\mathrm{a}}$ & \multicolumn{2}{l}{ Mean $\pm \mathrm{SD}^{\mathrm{b}}$} & $P$ value \\
\cline { 2 - 3 } & HCV-non-infected & HCV-infected & \\
\hline Creatinine $(\mathrm{mg} / \mathrm{dL})$ & $5.6 \pm 0.3$ & $5.9 \pm 0.2$ & 0.426 \\
Blood urea $(\mathrm{mg} / \mathrm{dL})$ & $128.6 \pm 5.7$ & $125.3 \pm 6.6$ & 0.709 \\
S. sodium $(\mathrm{mmol} / \mathrm{L})$ & $142.1 \pm 0.6$ & $142.3 \pm 0.7$ & 0.877 \\
S. total calcium $(\mathrm{mg} / \mathrm{dL})$ & $8.3 \pm 0.1$ & $8.4 \pm 0.1$ & 0.378 \\
S. potassium (mmol/L) & $4.7 \pm 0.1$ & $4.6 \pm 0.1$ & 0.672 \\
\hline
\end{tabular}

Reference ranges: creatinine, $0.7-1.4 \mathrm{mg} / \mathrm{dL}$; blood urea, $20-40 \mathrm{mg} / \mathrm{dL}$; $\mathrm{S}$. sodium (Na), 135-145 mmol; S. total calcium (Ca), 2-2.6 mmol/L (8.5-10.2 mg/ $\mathrm{dL}) ; \mathrm{S}$. potassium (K), $3.5-5 \mathrm{mmol} / \mathrm{L}$

${ }^{\mathrm{b}} \mathrm{SD}$ standard deviation between the two groups in renal function parameters

differences between two the groups in the albumin level $(P=0.0001)$ (Tables 3 and 4$)$.

In the present study, we found that total MIS score was significantly higher in the $\mathrm{HCV}$-infected group than the non-HCV group (Table 5).

\section{Discussion}

In the current study, the male to female ratio was $32 / 14$ in infected $\mathrm{HCV}$ on haemodialysis that reflected increased incidence of $\mathrm{HCV}$ infection among males.

Our findings agreed with those recorded in Sudan among haemodialysis patients [8]. In both groups, there was decreased haemoglobin level which was below normal as it was $8.8 \pm 0.2 \mathrm{~g} / \mathrm{dL}$ in the non$\mathrm{HCV}$ infection group and $8.4 \pm 0.2 \mathrm{~g} / \mathrm{dL}$ in the $\mathrm{HCV}$ infection group. That was in accordance with the findings of Boubaker et al. [9].

Platelet count was less in the HCV group than in the negative $\mathrm{HCV}$ group although this difference was still non-significant [10].

We found that serum albumin was significantly decreased in the $\mathrm{HCV}$ infection group when compared with the non-HCV infection group. These findings agreed with the findings of Barakat et al. [11].

Table 4 Association of iron metabolism markers and other biochemical parameters with HCV infection

\begin{tabular}{llll}
\hline Parameter $^{\mathrm{a}}$ & \multicolumn{2}{l}{ Mean $\pm \mathrm{SD}^{\mathrm{b}}$} & $P$ value $^{c}$ \\
\cline { 2 - 3 } & HCV-non-infected & HCV-infected & \\
\hline TIBC $(\mu \mathrm{g} / \mathrm{dL})$ & $295.9 \pm 6.7$ & $292.6 \pm 5.1$ & 0.707 \\
Serum transferrin & $645.1 \pm 78.6$ & $457.3 \pm 53.3$ & 0.055 \\
Albumin $(\mathrm{g} / \mathrm{dL})$ & $3.7 \pm 0.1$ & $3.2 \pm 0.1$ & 0.0001 \\
CRP $(\mathrm{mg} / \mathrm{L})$ & $18.3 \pm 2.8$ & $22.9 \pm 3.2$ & 0.282 \\
\hline
\end{tabular}

${ }^{a}$ Reference ranges: total iron-binding capacity (TIBC), $250-410 \mu \mathrm{g} / \mathrm{dL}$; serum transferrin, 200-350 mg/dL; albumin, 3.5-5.5 g/dL; C-reactive protein (CRP), $5-10 \mathrm{mg} / \mathrm{L}$

${ }^{\mathrm{b}} S D$ standard deviation

${ }^{c} P$ value: $P>0.05$ is non-significant and $P<0.05$ is significant 
Table 5 The frequency distribution of the MalnutritionInflammation Score in HCV-infected group compared to noninfected group

\begin{tabular}{llll}
\hline MIS* & HCV-non-infected $(N=50)$ & HCV-infected $(N=46)$ & $P$ value \\
\hline $0-5$ & $12(24 \%)$ & $3(6 \%)$ & \\
$6-10$ & $23(46 \%)$ & $20(40 \%)$ & 0.035 \\
$11-15$ & $14(28 \%)$ & $18(36 \%)$ & \\
$16-20$ & $1(2 \%)$ & $5(10 \%)$ & \\
\hline
\end{tabular}

*Data are presented as $n$ (\%), and $P$ values were calculated using Pearson's chi-square test

In our study, we found that there was no significant difference in the level of transferrin in the HCV-infected group HD and HCV-non-infected group HD; however, the values in both groups were more than the normal range. These findings were matched with a previous study carried out by Bharadwaj et al. [12].

In maintenance haemodialysis patients (MHD), inflammation was also a well-known feature; we found that serum CRP in both groups showed increased level than the known normal level of CRP. That was in accordance with the findings of Al-Amir et al. [13]. The MIS is a comprehensive scoring system that considered prospective shortterm hospitalisation, mortality, nutrition, inflammation, and anaemia in maintenance haemodialysis patients [14].

Table 6 Correlation of the MIS with demographic and laboratory parameters

\begin{tabular}{lll}
\hline Parameter & $r$ & $P$ value \\
\hline Height & -0.176 & 0.087 \\
Body weight & -0.254 & $\mathbf{0 . 0 1 2}$ \\
BMI & -0.404 & $\mathbf{0 . 0 3 0}$ \\
Haemoglobin & -0.043 & 0.677 \\
RBCS & -0.094 & 0.363 \\
WBCS & -0.130 & 0.207 \\
Platelet count & -0.077 & 0.455 \\
Creatinine & -0.018 & 0.860 \\
Blood urea & -0.078 & 0.450 \\
S. sodium & 0.029 & 0.780 \\
S. total calcium & 0.158 & 0.072 \\
S. potassium & 0.029 & 0.783 \\
Total iron-binding capacity & -0.063 & 0.544 \\
Serum transferrin & 0.093 & 0.368 \\
Albumin & -0.378 & $\mathbf{0 . 0 0 0 1}$ \\
C-reactive protein & -0.072 & 0.486 \\
HCV infection & 0.287 & $\mathbf{0 . 0 0 5}$ \\
Viral load & 0.501 & $\mathbf{0 . 0 0 0 9}$ \\
BMI body mass & &
\end{tabular}

$B M I$ body mass index, MIS Malnutrition-Inflammation Score, $r$ correlation coefficient; $P$ value: $P>0.05$ is non-significant and $P<0.05$ is significant
A previous study of HD patients reported that the presence of active HCV infection, detected by molecularbased testing, is associated with certain clinical features that are suggestive of MICS [4].

We found that $\mathrm{HCV}$ infection was associated with a higher MIS score values (Table 6) which was in accordance with the findings of Tsai et al. [15].

\section{Limitations}

Not all patients agree to be in a research easily in addition, high price of elastography so could not be done.

\section{Conclusion}

The prevalence of malnutrition is higher in patients with positive hepatitis $C$ virus than non-hepatitis $C$ virus haemodialysis patients.

\section{Recommendations}

Routine nutritional screening and assessment at diagnosis of chronic kidney disease patients.

\section{Abbreviations}

BMI: Body mass index; CBC: Complete blood count; CKD: Chronic kidney disease; CRP: C-reactive protein; ELISA: Enzyme-linked immunosorbent assay; HCV: Hepatitis C virus; MICS: Malnutrition inflammation complex syndrome; MIS: Malnutrition inflammation score; SPSS: Statistical Package for the Social Sciences

\section{Acknowledgements}

Much gratitude is paid to all persons who helped in this work.

\section{Authors' contributions}

All authors have read and approved the manuscript. FAFR: manuscript review, design, and final revision. NAFA: idea of the study, manuscript editing, publishing, and follow-up (CA). SESA: laboratory studies. MAGH: literature search, clinical, statistics, and data collection.

\section{Funding}

Not applicable.

\section{Availability of data and materials}

The datasets used and/or analysed during the current study are available from the corresponding on reasonable request.

Ethics approval and consent to participate

Study protocol was investigated and approved by the Medical Ethics Research Team, Faculty of Medicine, Mansoura University. Every case, after guaranteeing privacy, has given informed written consent (code number MS/ 906).

Consent for publication

Not applicable.

\section{Competing interests}

The authors declare that they have no competing interests.

\section{Author details}

${ }^{1}$ Faculty of Medicine, Mansoura University, Mansoura, Egypt. ${ }^{2}$ Dialysis Unit, Sherbeen Hospital, Dakalia, Egypt. 
Received: 8 August 2019 Accepted: 28 February 2020

Published online: 01 May 2020

\section{References}

1. Mutimer D, Aghemo A, Diepolder H, Negro F, Robaeys G, Ryder S (2014)

EASL clinical practice guidelines: management of hepatitis $C$ virus infection. J Hepatol 60:392-420

2. Pawlotsky J-M, Panel members, Alessio Aghemo, David Back, Geoffrey Dusheiko, Xavier Forns et al (2015) EASL recommendations on treatment of hepatitis C. J Hepatol 63:199-236

3. Norberto P, Dario C, Bikbov B, Giuseppe R (2009) Hepatitis C infection and chronic renal diseases. Clin J Am Soc Nephrol 4:207-220

4. Kalantar-Zadeh K, Miller LG, Daar ES (2005) Diagnostic discordance for hepatitis C virus infection in hemodialysis patients. Am J Kidney Dis 46: 290-300

5. Kuhlmann M.K. and Levin N.W. Interaction between nutrition and inflammation in hemodialysis patients. Contrib Nephrol 2005 I; 149:200-207.

6. Ekramzadeh M, Sohrabi Z, Salehi M, Ayatollahi M, Hassanzadeh J, Geramizadeh B et al (2014) Adiponectin as a novel indicator of malnutrition and inflammation in haemodialysis patients. Iran J Kidney Dis 7(4):304

7. Steiber AL, Kalantar-Zadeh K, Secker D, McCarthy M, Sehgal A, McCann L (2004) Subjective global assessment in chronic kidney disease. J Ren Nutr 14(4):191-200

8. Abdalla EAM, Shabban KMA, Elkhidir IM (2016) Haemodialysis patients at dialysis centers in Khartoum State - Sudan. OSR-JDMS 16(3):83-88

9. Boubaker K, Mahfoudhi M, Battikh A, Bounemra A, Maktouf C, Kheder A (2015) Higher endogenous erythropoietin levels in hemodialysis patients with hepatitis $C$ virus infection and effect on anemia. Open Journal of Nephrology 5:29-34

10. Wai CT (2013) and his colleagues. Correcting thrombocytopenia in patients with liver diseases: a difficult hurdle. J Gastroenterol Hepatol 28:207-221

11. Barakat AA, Nasr FM, Metwaly AA, and Morsy S Eldamarawy M. Atherosclerosis in chronic hepatitis $C$ virus patients with and without liver cirrhosis. Egypt Heart J 2017 31; 69(2): 139-147.

12. Bharadwaj S, Ginoya S, Tandon P, Tushar D, Gohel TD, Guirguis J et al (2016) Malnutrition: laboratory markers vs nutritional assessment. Gastroenterology Report 4:272-280

13. Al-Amir MA, Hassan AA, Elshafie SM, ZeinElabdin HM, Taha SA (2017) The relationship between anemia, serum hepcidin levels, and chronic hepatitis $C$ in chronic hemodialysis patients. Egypt J Intern Med 29(6):112

14. Ho LC, Wang HH, Peng YS, Chiang CK, Huang JW, Hung KY, Hu FC, Wu KD (2008) Clinical utility of malnutrition inflammation score in maintenance hemodialysis patients: focus on identifying the best cut-off point. Am J Nephrol 28:840-846

15. Tsai H-B, Chen P-C, Liu C-H, Hung P-H, Chen M-T, Chiang C-K, Kao J-H et al (2012) Association of hepatitis C virus infection and malnutritioninflammation complex syndrome in maintenance hemodialysis patients. Nephrol Dial Transplant 7:1176-1183

\section{Publisher's Note}

Springer Nature remains neutral with regard to jurisdictional claims in published maps and institutional affiliations.

\section{Submit your manuscript to a SpringerOpen ${ }^{\circ}$ journal and benefit from:}

- Convenient online submission

- Rigorous peer review

- Open access: articles freely available online

- High visibility within the field

- Retaining the copyright to your article

Submit your next manuscript at $\boldsymbol{\nabla}$ springeropen.com 